\title{
Traditional Banks Conversion Motivation into Islamic Banks: Evidence from the Middle East
}

\author{
Farooq Salman Alani ${ }^{1}, \&$ Hisham Yaacob ${ }^{1}$ \\ ${ }^{1}$ Department of Accounting \& Finance, Faculty of Business, Economics \& Policy Studies, University of Brunei \\ Darussalam, Brunei Darussalam \\ Correspondence: Farooq Salman Alani, Department of Accounting \& Finance, Faculty of Business, Economics \\ \& Policy Studies, University of Brunei Darussalam, Gadong BE 1410, Brunei Darussalam. Tel: 673-874-1968. \\ E-mail: farooq.alani@ubd.edu.bn
}

Received: September 14, 2012

Accepted: October 17, 2012

Online Published: November 7, 2012

doi:10.5539/ibr.v5n12p83

URL: http://dx.doi.org/10.5539/ibr.v5n12p83

\begin{abstract}
The increasing awareness on Islamic banking and finance has created a huge demand for shari'ah based or shari'ah compliant products. Banks, especially are trying to capture this huge market by either converting themselves into a full fledge Islamic banks or opening a window for the Islamic based transactions. This study highlights the reasons why traditional banks turned towards Islamic model. The phenomenon of traditional banks turning into Islamic form was reinforced by the success of these banks averting the recent world economic crises. This study examined this phenomenon through four axes, first is the law, second is the risk and profit rates, third is about the customer needs for Islamic products, final one the lessons of successful conversions the region. This study concludes that there is a statistical significance between the trend towards the switching to Islamic banks and the low risk nature with high levels of profits that characterized Islamic banks. Also, religious (Islam) has influenced the conversion towards Islamic model. The study put forward several recommendations. Perhaps the most important call is to unite, integrate and increase interdependence between the Islamic banks. It is also important for the Islamic banks to innovate and create new products for the benefit of the consumers at large.
\end{abstract}

Keywords: Islamic banks, traditional banks, shari'ah, riba', investments, depositors

\section{Introduction}

Studies have indicated that the volume of Islamic investment banks will have assets up to $\$ 3$ trillion over the next five years (Yaacob, 2012). The Middle East region, especially witnessed conversion of traditional banks into Islamic form. Over the last two years, four banks turned from traditional model into Islamic form in the state of Kuwait only, in addition to the opening of Islamic banks branches and products next to traditional banking products. This conversion has taken two-way, first, open Islamic branches and divisions inside these traditional banks which means dealing with products similar to Islamic one or buy a fully Islamic bank. Second is the full conversion to Islamic form.

The question here (what are the motivations or reasons behind transforming the traditional banks into Islamic form), this study is based on three basic assumptions as follows, 1) There is a statistically significant relationship between forms of finance, risk and traditional banks conversion towards Islamic form; 2) Banks that follow Islamic foundations more successful than traditional one because they are compatible with the needs and desires of customers in the region; and 3) There is a statistically significance relationship between Islamic culture of banks customers and transformation into Islamic model. The study aims to highlights the motivation or reasons behind this kind of turn from traditional banks to Islamic banks and also reasons of success of these banks and clarification for the people dealing with these banks if this turn stems from caring in Islamic law or for other reasons.

The samples of this research are two banks in Kuwait, one of them fully shift to Islamic bank and the other national bank of Kuwait open an Islamic window. The research instrument is a questionnaire distributed to senior management in these banks to keep track of their views and analyzed statistically based on the analysis of the descriptive document connected to logic and facts to follow the reasons behind this turn. 
The paper is organized into three sections: first deals with Islamic and traditional banks and the second shift mechanisms either the third section discusses the implications of the turn from traditional banks into Islamic model and finally conclusions and recommendations.

\section{Islamic Banks}

There is definite definition for Islamic banks, but one of the major objectives is the prohibition of riba' and interest (Anas \& Mounira, 2009; Widagdo \& Ika, 2008, p. 98; Yaacob, 2012). The Islamic banks are responsible and accountable for the use of depositors fund, and as an Islamic institution, the accountability is not just to depositors, it include the stakeholders and ultimately to God (Nahar \& Yaacob, 2011). Common definition of the Islamic bank is a bank does not take benefit (Abdul Rahman, 1995) that a financial institution receives deposits from people without consequences benefits but invest it directly by participating with businessmen and investors on the basis of loss and gain without benefit only.

The previous definition which made a distinctive substantial difference between Islamic banks (without benefits) and traditional banks (with benefits) concentrate on one important reason of not dealing with benefits which is very necessary for Islamic banks but not enough to demonstrate the comprehensive concept of Islamic banks, and perhaps this confirms when some traditional banks relied on alternative systems of interest (Fadi, 2004) for example, village banks or saving banks in Germany in the thirties of the last century. Experience applied in West Germany after World War II, which managed the German economy to regain its position and rise from the abyss to which deteriorated due to World War II as well as banks in former socialist bloc (the soviet union) was depending firstly on central planning system in the creation and distribution of financial resources. Lease financing is one of the most important activities of banking begun in the early sixties, a process that rent all equipment from small items to office tools and aircraft carriers and tankers where the bank buys assets, equipment and renting them to others for specific wages depending on certain condition as well as give the tenant the right to own property for more information (see MahfothJawda, lease financing banks in Jordan Magazine, issue 1, volume 18, January-February 1999, p. 49).Some traditional banks also deals with capitalism have variety of experiments now.

We can define Islamic banks as an institution that practice banking with its commitment by avoid dealing in benefits and stay away from any other act contrary to Islamic law (Fadi, 2004); here we find another foundation besides not dealing with benefits and avoiding any action in contravention of the provision of Islamic law through not investing in forbidden projects like night clubs, manufacturing and marketing alcohol beverages companies, however this definition does not reflect full images of the Islamic bank reality by ignoring basic feature of Islamic banks work which is social responsibility (Sawi, 2001). Here came the third definition of which gives an indication on Islamic banks work and ignore the first two definitions Islamic banks are financial institutions aims to collect money and employ them in accordance to Islamic law in order to serve Islamic solidarity community and make justice in distribution, with commitment not deal with benefits and avoiding any action in contravention of Islamic law (Moaid, 1998).

The social responsibility of Islamic bank represent by giving money for poor people (zakat) about his money and depositor money when pass one year of deposit according to proportion decided by Islamic law (Al Qaradhawi, 1998), for the application of non-economic objectives including ideological and moral purposes not used in traditional banks which governed by purely economic criteria aimed to maximizing profits. The free interest loan given to needed people is the best example for the big social responsibilities role of Islamic banks also these loans give to people who in real need for money to marry or recruitment as well as helping small and middle projects. This is one of the ethical investments by the Islamic banks and it is also a part of the institution's corporate social responsibilities (Anas \& Mounira, 2009). Finally, we can define Islamic banks as financial institutions operating under Islamic law for community service and development first and make a profit secondly using formulas and methods distinguish by regeneration to suit the age we live (Sawi, 2001)

\subsection{Goals and Characteristic of Islamic Banks}

Despite the fact that every Islamic bank has objective seek to achieve differ from others but we find there are common goals and semi-public goals most Islamic banks seek to achieve and can be summarized as follows (Mohsen, 1990), 1) Achieve economic development and social progress of the peoples in Islamic law legitimacy framework; 2) Raising awareness of Islamic banking and develop citizens trust in these banks and economic system as the most suitable system for the people in order to develop economic and social progress of Islamic countries and face number of problems and crisis in these societies; 3 ) Develop Islamic banking tools and invent new one to mobilize new resources and channels to be employed and covers needs of individuals; 4) Achieve economic integration between Islamic countries through the ability of these Islamic banks to direct investment 
for economic elements linked to these countries, such as the development infrastructure facilities of transport routes land, air and sea and different means of communication; 5) Solve problems in economic systems based on traditional theories of finance and development and find balanced economic and social system based on direct credit and investment employment policies presented by Islamic banks (Ausf, 1987); and 6) Develop trading between Islamic countries because trading is a gateway for economic integration and result of it at the same time, in addition to the role trade played in increasing economic and social degree between Islamic people and liberate them from economic dependency of developed countries (Fadi, 2004).

The characteristic of Islamic banks after addressing the concept of these banks as financial institutions operating within the framework of Islamic law which aims to serve and develop community first and then make a profit secondly using advantage investment methods and regeneration to suit the age, according to this concept Islamic banks have some distinguish features differ from traditional one which principally based on financial intermediation process but Islamic banks have unique style in mobilizing financial resources of cash surplus owners (depositors and investors), and giving these resources to need people (loan applicants and investors) so we find this concept draw a new social and economic dimensions.

We can identify three important characteristics of Islamic banks apart from traditional banks (Fadi, 2004): 1) ideological character, Dealt with many books, articles and research characteristic of Islamic banks, but was used in this study, the reference above about the classification of properties only; 2) Development character; and 3) Social status.

\subsection{Funding Sources and Fund Uses in Islamic Banks}

Funding sources consider the main source of money for Islamic banks which support investment projects by using this money to implement plans and main activities of these banks; through our perception of how life looks without water we can imagine banks to be without money, most writers, researchers, specialists in Islamic banks field agreed to divide the funds sources into two main sources:

\subsubsection{Internal Funding Sources}

Include equity which represent; (capital, reserves, and retained earnings) (Mohamed, 2008), and some other resources as follows:

1- Shareholders' equity: consists of paid-up capital, reserves, and retained earnings, the following discussion of the terms of shareholders' equity:

A- Capital: the capital of the Islamic banks comes from money paid by the founders and shareholders when inception compared to the nominal value of the issued shares (IPO process) or against an increase in capital employed by banks in order to provide long-term internal funding sources, and usually invests part of capital in fixed assets which cannot be benefit in funding (Mohamed, 1996).

B- Reserves: it represents profits held from previous years and ducted from the share of shareholders and does not consists only of the profits or surplus funds and consolidate and strengthen the financial position of the bank, there are several types of reserves including the legal reserve and statutory reserve (Youssef \& Mohamed, 1989).

C- Retained earnings: represent profits paged for the next fiscal years based on the decision of the board of directors and approval of the general assembly on the financial and economic purposes (Youssef $\&$ Mohamed, 1989).

\section{2- Provisions.}

3- Other resources: there are other resources available to Islamic banks, such as free-interest loans from shareholders, and depositor insurance by customers as a letter of credit or guarantee and the value of secure safes leased (accountant's board, 2002).

The internal sources of funds in Islamic banks consider long-term sources in case of whether its ratio compared to external sources very big which can be invested in long-term projects, and in case it represent small percentage cannot be invested.

\subsection{External Funding Sources}

This includes various deposits in Islamic banks like demand deposits (current accounts), saving deposits (savings), investment accounts (investment deposits), saving Islamic books (Mohamed, 2008), and others: 1) Demand deposits (current accounts); 2) Savings deposits (savings), Saving deposits are considered as one of the types of deposits in Islamic banks which is divided into two parts (Mohamed, 2008):

A- A savings account with a mandate to invest 
B- A savings account without authorization to invest

\subsubsection{Investment Deposit (Investment Account)}

Deposit money in Islamic banks in order to obtain a return as a result of investing from these banks and these funds are subject to legitimate base pays.

\subsection{Joint Investment}

It is also considered as one of the funds sources in Islamic banks, which is an alternative to investment certificate and bonds (Ahmed,1989), and these check are applied to contract formula speculation where money from one party (owners of the check) and work from other party (the bank) and these checks could be restricted or absolute due to the quality of the check and profits can be divided on the basis of the deposit sum (Ahmed, 2004), and these checks can take the following forms, 1) Investment check allocated for specific project; 2) Investment check allocated to a particular activity; 3) Public investment check; 4) Joint checks or custom (Ahmed, 2004); and 4) Islamic savings books.

One type of savings deposits in Islamic banks which can be deposit and withdrawal of these books at any time (Jordan Islamic bank, 1987).

\section{1- The Islamic financial institutions deposits}

2- Certificates of deposits

\section{3- Investment funds or investment portfolio}

The uses of money in Islamic banks can be divided generally on the following aspects, 1) Monetary assets: include cash in hand, cash at other banks, and balances in the central bank; 2) Financing and investment: it includes various financing activities practiced by the bank, such as: participation, profitable, rent finished by ownership; 3) Good loan; and 4) Direct capital investment: it includes exchanges (shares, investment portfolios, investment funds) participation in projects, company establishment, and commodity stocks and trades (Mohamed Albeltagy, 1987)

\subsection{Finance and Investment (Indirect Investment)}

In this type of investment bank in conjunction with natural or legal persons established a new project or participate in existing one has a specific legal form (Mohamed, 2001), and the most important forms are these formulas addressed by the study are not all formulas of investment carried out by Islamic banks, but taking some common formulas used by most Islamic banks such as Dubai Islamic bank, Jordan Islamic bank, the Islamic development bank, Sudanese Islamic bank, and Faisal Islamic bank of Egypt (for more information about the rest of formulas see D. Ahmed Sofar, Islamic Banking).

\section{1- Exchange contract}

2- Participate contract

3- Commercial contracts

a- Exchange contract for order of buy

b- Bargaining contract

Financing formulas distinguish by different flexibility to meet the needs of diverse customers and all economic sectors as each version of those formulas can be used to finance the activity cannot finance by other formulas, what is fit for profitable finance cannot be funded by manufacturing funds and so on. (Tewfik, 2009)

\section{Concept and Characteristic of Traditional Banks}

Traditional banks are (economic unit exercised the financial intermediation process between the relevant authorities have fiscal surplus and those with fiscal deficits and exchange for returns due to the exercise of these mediation) (Cup, 1979). We can define traditional banks also as; (financial institutions dealing with money by accepting deposits, maintain and developing loans, banking facilities and invest in different exchanges like stocks, bonds and other financial checks) (Khalid, 2004). Traditional banks also defined (financial institutions that borrow from people who their incomes higher than spending and lending the money to people who spend more than current income) (Sayers, 1967).

We can summarize the characteristic of traditional banking by the following paragraphs:

1- Traditional banks are economic institutions operating through economic criteria aim only to achieve profits to maximize the wealth of the owners. 
2- Traditional banks relationship with customers like creditor and debtor where is embodied through the process of lending and borrowing with interest rate.

3- Traditional banks create credits by lending in interest rate and funds go to production processes or trade directly.

4- Depositors in traditional banks get a predetermined return whether bank loss or make profit.

5- Traditional banks aimed to lend with interest and care about guarantees provided by the borrower and financial suitability and credit worthiness it financed to people who are able to repay the loan amount and interest result from lending, and is not important where the money will be used by the lenders.

6- The traditional banks revenues are guaranteed only in case borrower's insolvency or bankruptcy or refraining from payment.

7- Capital function in traditional banks is to protect depositors' money and absorb the losses that might be achieved.

\subsection{Funding Sources and Money Uses in Traditional Banks}

Funding sources in Islamic banks can be divided to internal and external sources of funding:

First: internal sources of funding;

1- The paid-up capital

2-Reserves: amounts deducted by the bank from net profit to distribute it on shareholders which is divided into: (Hassan, 2005)

a- Statutory reserves: bank commitment to create in light of legal text.

b- Optional reserves: the bank created voluntary.

\section{1- Provisions}

2- Retained earnings (undivided profits).

Second; external sources of funding: Money the bank gets from outside as a liabilities consists of the following elements:

\subsubsection{Deposits}

The main source of funds for banks and deposits size consider as indicators used to measure the size and position of the bank so the banks deposit is the main source of commercial funds of banks, and the study of bank deposits is an introduction to the study of the rest of the banking operations, because bank deposits is the main introduction for the bank to directly active in the creation of credit and lend (Khalid, 2004).

a- Minus deposit (cash):

Includes four types: (current deposits, savings deposits, prior notice deposits, and finally total deposits safes).

b- Deposits of other banks.

c- Different cash insurance.

d- Loans from central bank and other sides.

1- Other sources of funding: some banks use special bonds issue for specific projects they finance or manage it which consider one kind of funding source for these banks.

Fund uses in traditional banks are: represented in the way they invest the money under bank possession to achieve goals (survival, growth and increase wealth of agents) on the other hand achieve bank goals (achieving the advancement of the society to provide a useful service for the society and contribute in economic and social projects).

Deposits structure and funds play an essential role in investment formation (assets) and money employed by the bank deepened on deadlines, quality and level of deposits also the depositor's awareness with great consideration to economic and political conditions and legislature.

When bank manage deposits money trying hard to harmonization between liquidity, profitability and safety, bank puts part of assets in liquid balances and employs part in profitable assets, in seeking to achieve goals bank behaves like any rational investor in the requirement of funds available for investment and chose projects that yield high return and less risky between available alternatives, if all the returns will be equal then bank chose less risky investment and if all investment equal in risky then bank will chose highest investment returns. 
The bank in order to achieve objectives in serving customers and make profits, must develop general liquid policies which means determining the quantities of money that must be put in different types of loans, and to give information on the nature of banks deposits as there are overlapping relationship between deposits types and assets types acquired by the bank of those deposits (Hassan, 2005).

They divided aspects of money uses in traditional banks into the following forms:

First; direct facilities: given directly to banks customers.

Loans: this function is the first and main investment for traditional banks where loans were granted to a wide variety of clients although they prefer it historically "for granting short-term loans". Bank loans consider the most important sources of external funding to businesses in most countries in the world, and this function stayed as main part of the banks work until few years, where banks begun using broader concepts than giving loans to investment bank fund resources in the form of investment and loans (Mish, 1992).

Figure 1 illustrate the size of loans to businesses in four major industrial countries which are: United States, West Germany, Japan, and Canada and compared to other sources of funding:

Figure1; illustrates the volume of bank loans between sources of funding to businesses for a sample of developed countries.

This figure illustrate the volume of bank loans which was the most important sources of funding for businesses compared with other sources of funding in those countries, this help banks to develop strategies and concepts with good managing. We can classify traditional bank loans according to some essential principals depending on the important of loans type.

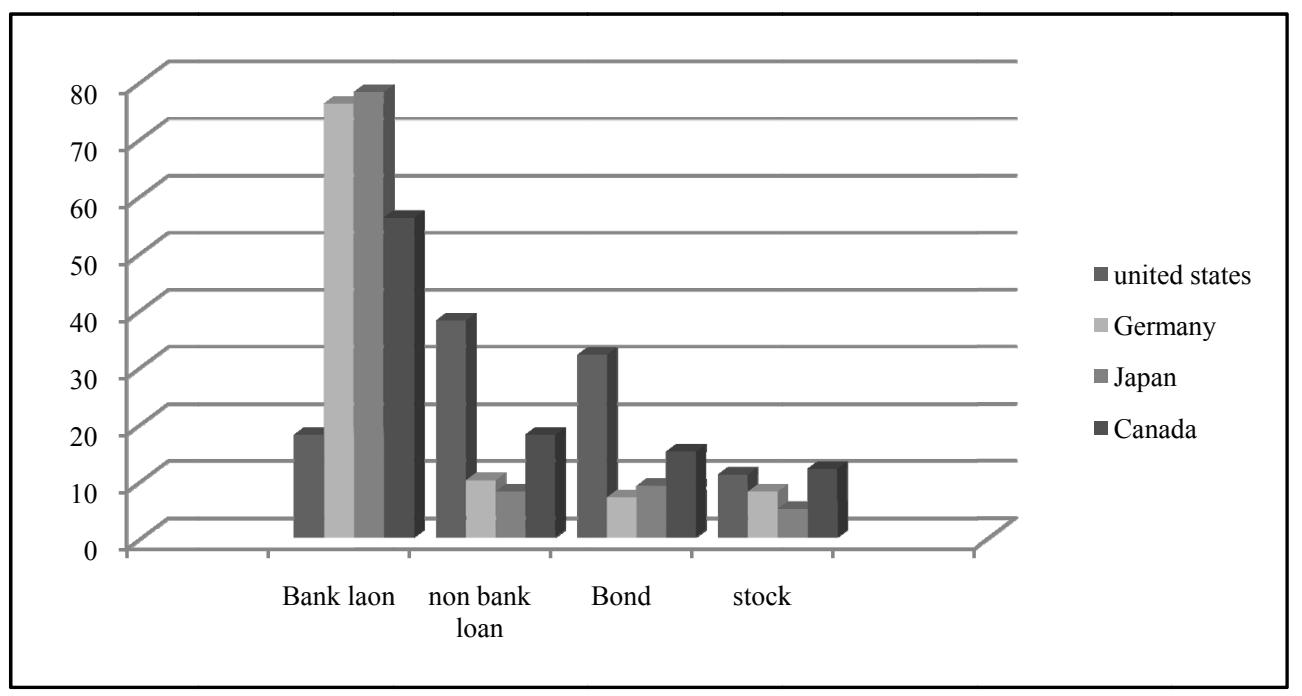

Source: Ferderies (1992)

Figure 1.

2- Open current accounts receivable for bank customers (overdrawn current account).

Second; indirect facilities:

1- Open documentary credits

2- Issuance of guarantee letters

3- Issuance of internal and external exchange and the value of internal and external received remittance.

Third; services and other investments:

1 -collect rights of customers from others

2-sale and purchase foreign currencies

3-rent iron lockers to save precious things

4-buy and sale foreign tourism checks and traveler checks, and cashing those different checks

5-buying and selling portfolio and fiduciary saved for the benefits of customers and issuance of portfolios 
instead of customers in addition to marketing those portfolios

6- postal, telegraphic and electronic transfer of money

7-bank credit card

Second topic: mechanism of traditional banks converting to Islamic form:

\subsection{Mechanism Using in Traditional Banks}

There are several formulas applied by traditional banks for the purpose of providing services and mechanisms in Islamic banks for customers and these formulas are:

\subsubsection{Islamic Investment Funds}

In this method, the bank established of investment funds depending on the methods of Islamic investment, and these funds in general is a money pot seeks to collect savings of individuals and invested in portfolios through a specialized expertise and efficiency in the management of portfolios (Saeed, 1999). The adaptation of these funds in terms of legitimacy as a contract between the fund Management Company and shareholders, whereby shareholders pay certain amounts of cash to fund management, which undertakes to invest such sums in buying and selling portfolios in accordance with the provisions of the Islamic law, and shareholders divide profits resulting from the fund's investment all at the same percentage of shares depending on the terms of the prospectus.

\subsubsection{Islamic Windows (Islamic Units)}

Given the weak credibility of open duplication (unrestricted) to provide Islamic banking services side by side with traditional banking services, what may be accompanied by a relative weakness in achieving breakthroughs market targeted by the banks that have adopted this approach, other banks turn to address this shortcoming by opening windows / Islamic units in traditional branches or at their headquarters, Islamic windows means generally that traditional banks allocate part or space in traditional branches to provide Islamic banking services as well as provided traditional services (saeed, 1999).

This method is intended primarily to meet the needs of some customers who want to handle the Islamic banking system so as not to turn into a deal with Islamic banks, be specialized in the sale of Islamic products and services but not others, examples of this category of banks include (directory of Islamic banks, 2005):

a- Dresdner Kleinwort Benson Bank, who founded a specialized unit of Islamic banking (1988).

b- New Zealand and Australia ANZ group, which established a special section of Islamic finance (1996).

c- Citibank Bank who founded a specialized Islamic financing unit (1966).

\subsubsection{Transfers}

Banks has transferred branches to traditional Islamic branches and established new Islamic branches: Against the two entrances which was motivated commercially, there were some traditional banks which organizers wanted to made it Islamic banks as all by passing the purely commercial objectives, and the entrance to this category of banks by engaging in the process of gradual convert through the creation of a separate department of Islamic banking to achieve goals, and we can defined the Islamic branches as "branches established by traditional banks to offer Islamic banking services" (Saeed, 1999).

Run by experts and specialist in Islamic banking, like key management departments of the bank, the administration took the task of developing strategic plans starting in transfer some traditional branches to Islamic one completely and establishing Islamic window in traditional banks in carefully selected locations to ensure the greatest chances of success in light of duplication "codified" to provide Islamic banking services and traditional together in order to further guarantee the safety of the application and gain more public confidence in Islamic banking departments in these banks by formatting of independence oversight bodies legitimacy to their work includes a number of senior scientists who combine between knowledge of law and economic also some members of the bank, which had undesirable effect on the growth speed of Islamic banks and ability to compete with traditional banks.

Examples of this category of banks are the following (directory of Islamic banks, 2005):

a- Saudi National Commercial Banks, which is one of the largest banks operating in the Arabian Gulf and Middle East.

b- National bank of Kuwait that bought Boubyan Islamic Bank, which is an Islamic window of the national bank. 


\subsubsection{Fully Transferred to Islamic Form}

Those banks beliefs that this route is the wiser way and the fastest and most deserve to gain customers confidence in the integrity of the application, perhaps helping these banks to achieve objectives is the relative small size of Islamic market and the easy way to rehabilitate employee to operate this work in new form. Examples of this category of banks are the following (directory of Islamicbanks, 2005):

a- National Bank of Sharjah, United Arab Emirates, which has already completed the process of transformation desired.

b- Aljazerah Bank in the Kingdom of Arabia Saudi, who made good progress in the direction of transformation.

c- Mortgage bank fully turned to Islamic model represented by international way.

\subsubsection{Islamic Financing Instruments}

The traditional banks in this method provide some tools or Islamic modes of financing such as participation, speculation and exchange in stocks to attract a customer that want to deal in accordance to Islamic law, most traditional banks in Saudi present these formulas or products with a different level and presentation with legal compliance in practical application of these tools or formulas.

Although the idea of setting up branches or Islamic windows in traditional banks has received some significant support among existing people in Islamic banks, but it also has received some opposition from other segment interested in Islamic bank.

1- Point of view in favor of establishing branches / Islamic windows in commercial banks.

a- Recognition of the economic viability of Islamic banking

b- Recognize the realistically practical applications of Islamic banks model, and that idea goes beyond just raising slogans or emotions (saeed, 1999).

c- The opportunity to benefit from the experiences of these commercial banks in the development of Islamic products and human cards of Islamic banking in general.

d- Promoting coexistence between the two banking systems (Youssef, 1996).

2- the opposition point of view to the establishment of branches / Islamic windows in commercial banks are:

a- Fear that leads to depression in application in customers and employee minds.

b- Fear that application of two different systems in one banks will made loss for that bank. ( saeed, 1999).

c- Delayed establishment fear of new Islamic banks.

\subsubsection{Obstacles}

These constraints vary according to the situation of the bank and also vary in importance degree among banks that choose to open Islamic window only and banks that choose to convert traditional bank to private Islamic bank and these constraints are as follows:

1 - obstacles related to administration

2- human resources constraints

3- technical obstacles

4- obstacles related to the development of products

5- market development obstacles

6- impediments related to the legitimate control

\section{Research Methodology}

The researcher used the descriptive analytical approach in regards to survey senior's directory in Islamic banks and traditional banks that offer Islamic services, and he mentioned to four Islamic banks in Kuwait state which registered in central bank and find two from those banks (Baitek and Bobuyan) has established originally as Islamic and two had convert from traditional to Islamic banks (mortgage bank convert into international and Middle East) and 10 traditional banks work in Kuwait the most great one is Kuwait National Bank, and for research purposes two banks were selected one of them convert from traditional into Islamic form (International Bank) and he choose also the National Bank as a sample of banks that open an Islamic window, the first chosen because was pioneer in converting experiments and very successful and the National Bank being open a separate Islamic window by buying Bobuyan Bank. The study uses a questionnaire (attachment paper No.1) includes 21 
questions divided on four subjects:

1- first subject (standard) which determine the commitment of banks in Shari'ah (Islamic law ) in converting decision, and includes five questions simulate the needs of Kuwait people to Islamic bank services and its impact on management decision of full or part converting to Islamic form, generally this subject explain a statistical relationship of the main cause of converting to Islamic banks and this hypothesis were accepted with $95 \%$ which support the presence of a statistically significant relationship of the subject and with percentage near $100 \%$ (Annex No.2).

2- second subject (standard) came to studying the impact of risk and high profit rates on the decisions of convert into Islamic bank, this subject includes four questions simulate the risk and profits impact on convert decision, and explains the general direction of no statistically significant difference in the forms of financing and risks are driven at banks to convert into Islamic form which accepted moral imposition by $95 \%$ that supports the lack of a statistically significant difference in the direction and views, the approval rate was between variables axle ratio total converge approval with reference to the different opinions on the fourth question may be due to confusion understanding between the benefits and risks that did not lead to statistical difference (Annex No.3).

3- third subject (standard) studied the customers need for Islamic services, also included four questions trying to follow banks customer need for Islamic services shows approaching approval $95 \%$ of the total approved, supports the hypothesis that say no statistical difference which meets the customer needs of Islamic services which is one of the most important reasons for converting into Islamic form (Annex No. 4).

4- The final subject studied the past experiences of transformation and its impact to pay banks to turn towards Islamic banks included three questions reflect the impact of the success or failure of previous experiences in convert decision towards Islamic banks, also analysis reflect the existence of statistical difference in the success of transformation experiments in global banks which was one of the main reasons that pushed towards accepting convert into Islamic banks with approval percentage $95 \%$ near $100 \%$ (Annex No. 5).

\subsection{Questionnaire and Statistical Analysis}

By reference to research hypothesis and result obtained have shown the following:

1- The second subject supports the first hypothesis which holds that risks and profits is the main reasons made banks adopt Islamic model and move away from traditional model.

2- For the third hypothesis has been reached sincerity by highlighting the statistical relationship with moral degree $95 \%$ accept that banks customer adhere in Islamic law which make banks offer Islamic services to achieve their desires and compatible with their beliefs which provide them with soul safety like explained in second and third subject.

3- Fourth subject and other explained dialectical link ratified the second hypothesis about the success of the bank through consensus with customers by meeting the needs of a specific type of services compatible with customer belief, as well as other subjects confirmed that an Islamic banks in safe position and far from risks compared to traditional banks based on the collaborative relationship and partnership with customers and not leading them, finally the fourth subject explained that Islamic bank shall make decisions with good study to the market.

\section{Conclusions and Recommendations}

The study found a number of conclusions:

1- Strong statistical relationship between traditional banks directed to Islamic model and risks faced by Islamic banks with the nature of the low and high profit rates characterized by Islamic banks.

2- Religious scruples control traditional banks customer prompting the administration to create Islamic services to meet their needs or convert to Islamic model.

3- Ways to use money and funding sources urges customers to deal with Islamic banks because found on the basis of partnership and direct communication, which makes them feel safe and reduce risk of non-payment a mutually reinforcing relationship.

4- The success of international experiences forms a reason to push some banks to turn towards Islamic model but with limitation because each bank depends on work environment.

5- The absence of supreme body of fatwa led to great difference in Islamic banks address to problems related to Islamic foundation law, which confounded Islamic banking.

6- The Islamic banking process proved feasibility and significant presence demonstrated by the feasibility of many ancient traditional banks like HSBC, City Bank, Deutsch Bank, Chase JP Morgan, to made contracts with 
many Islamic banks, investment and manage joint fund, open Islamic windows and branches, the international monetary funds and World Bank also established units for research and studies of the Islamic economy and Islamic banking rules, to provide tools and financial services that have been adapted to suit Islamic law requirements which traded in global financial markets, also many Muslim countries initiated Islamic banking system to meet the growing demand for Islamic financial services.

7- Lack of legislation concerning Islamic legal banks in spite of the release of some of the legislation within the range of banking laws in some countries including the bank under study.

As for the recommendations:

The study put several recommendations possible to serve Islamic banks and investment decision-makers in this sector, including:

1- Work to increase interdependence and integration between Islamic banks, mutual benefits and challenges.

2- To raise awareness of the importance of Islamic banking and its role in the Muslim community, especially after the failure of traditional banks tools to face the current financial crisis and the emerging of Islamic banks.

3- Emphasis on urging banks to innovate and create of Islamic services that characterized of survival, regeneration and continues.

4- Urged Islamic banks to invest in medium risk investment to give additional financial momentum and bring new segment such as speculation and rent.

5- Hold seminars and meetings to strengthen ties between Islamic banks and pushed it to integrate with each other.

6- Working on a mechanism to standardize fatwas legitimacy for Islamic banking transactions and develop a reference platform with work on adding everything new in this sense.

\section{References}

Abdul Rahman. (1995). The role of Islamic banks in the development. Islamic Economics Journal, No. 167.

Ahmed, M. A. (1989). The work of Islamic investment companies in the global market (1st ed.). Bahrain.

Ahmed, S. (2004). Islamic banks. Publications of the Union of Arab Banks, Lebanon.

AL Qaradhawi, Y. (1998). Contemporary goals of Islamic banks. Seminar on contemporary Islamic applications, Casablanca.

Anas, E., \& Mounira, B. A. (2009). Ethical investments and the social responsibilities of the Islamic banks. International Business Research, 2(2), 123-130.

Fadi, M. R. (2004). Islamic banks. human rights publications (1st ed.). Halabi, Beirut.

Ferderies, M. K. (1992). The Economics of Money Banking \& Financial Markets (3rded.). Harper Collins, Publishers, USA.

Hassan Bani Hani. (2005). money economies. the Canadian Dar, Amman.

Ibrahim Saidi. (n. d.). types of deposits in Islamic banks, Cairo.

Jordan Islamic Bank. (1987). fatwas legitimacy. Part II Press Release No. (6).

Journal of Accounting Standards. (2002). Accountants board to review the body of Islamic financial institutions. Manama, Bahrain: Journal of Accounting Standards.

Khalid, A. A. (2004). Banking operations (5th ed.). Dar Wael for publication, Amman, Jordan.

Moaid, A. Z. (1998). Central bank policies for organization of Islamic banking operations. Islamic Journal, 207.

Mohamed El-Beltagy. (1997). Criteria for evaluating the performance of Islamic banks (Ph.D. thesis). submitted to the Faculty of Commerce, University of Al-Azhar, Egypt.

Mohamed El-Beltagy. (2008). Islamic banks. Retrieved from: www.Biltaji.Com.

Mohammed Jalal Suliman. (1996). Investment deposits in Islamic banks, the Higher Institute of Islamic Thought.

Mohsen, K. (1990). Book of Islamic bank. AL Huria Dar for printing, Cairo.

Nahar, H. S., \& Yaacob, H. (2011). Accountability in the sacred context: the case of management, accounting and reporting of a Malaysian cash awqaf institution. Journal of Islamic Accounting and Business Research, 
2(2), 87-113. http://dx.doi.org/10.1108/17590811111170520

Saeed, S. A. (1990). Controls provide Islamic banking services in traditional banking. Economic Journal, Kuwait.

Sawi, M. (2001). Investment Problems in Islamic banks (1st ed.). Dar Wael, Amman, Jordan.

Sayars, R. S. (1967). Modern Banking. Oxford, Glarewdon Press, UK.

Tawfiq al-Bashir. (2009). Funding the Islamic Bank. Al Rajhi Magazine, 601.

The banking and Amassat guide Islamic finance - the International Union of Islamic Banks. (2005).

Widagdo, A. K., \& Ika, S. R. (2008). The interest prohibition and financial performance of islamic banks: Indonesian evidence. International Business Research, 1(3), 98-109.

Yaacob, H. (2012). Issues and challenges of shari'ah audit in Islamic financial institutions: a contemporary view. $3^{\text {rd }}$ International Conference on Business and Economics Research, Bandung, Indonesia.

Yousef, A., \& Mohamed, A. A. (1986). Introduction to Financial Accounting. That ALsalasil, Kuwait.

Youssef, K. M. (1996). Islamic banking crisis and director. Jordan.

\section{Appendix}

\section{Questionnaire form}

\section{First: identifiable information (descriptive)}

1- Age 20-30 (6) 31-40 (8) 40 and above (6)

2- Sex male (17) female (3)

3- Current job title managing director (5) branch directors (5) divisions director (10)

4- Years of experience

\begin{tabular}{|c|c|c|c|}
\hline $10-5$ & $10-15$ & $15-20$ & Above 20 years \\
\hline
\end{tabular}

$\begin{array}{lll}\text { 5- Certificates } & \text { below diploma } & \text { diploma () } \\ & \text { Bachelor }() & \text { high diploma () } \\ \text { Master () } & \text { Ph.D. () }\end{array}$

6- Specialty: most of the above disciplines was accounting, banks, administration ()

Islamic law () law () 


\section{Second: questionnaire axis}

Put mark in the field that it deems appropriate for your answer

\begin{tabular}{|c|c|c|c|c|c|}
\hline A- compliance with Shariah (Islamic Law) & $\begin{array}{c}\text { Agree } \\
\text { strongly }\end{array}$ & Agree & $\begin{array}{l}\text { Not } \\
\text { sure }\end{array}$ & $\begin{array}{l}\text { Not } \\
\text { agree }\end{array}$ & $\begin{array}{c}\text { Not agree } \\
\text { strongly }\end{array}$ \\
\hline
\end{tabular}

1- Banks faced customer are demanding Islamic products

2- Some customer don't deal with banks because of traditional products(kind of Riba)

3- Religious faith strongly controlled the Kuwaiti citizens

4- Number of customers increased when providing Islamic products

5- Is decision to shift into Islamic banks because of the demand of Islamic products.

\begin{tabular}{|c|c|c|c|c|c|}
\hline B- low rate of risk and increase profit & $\begin{array}{l}\text { Agree } \\
\text { strongly }\end{array}$ & agree & $\begin{array}{l}\text { Not } \\
\text { sure }\end{array}$ & $\begin{array}{l}\text { Not } \\
\text { agree }\end{array}$ & $\begin{array}{l}\text { Not agree } \\
\text { strongly }\end{array}$ \\
\hline Islamic products less risk than traditional & & & & & \\
\hline $\begin{array}{l}\text { 7- Participation concept enhances the profits because not dealing with credits and } \\
\text { non-recovery of money }\end{array}$ & & & & & \\
\hline $\begin{array}{l}\text { 8- Is the reason behind taking shifting decision because of profits gained from } \\
\text { Islamic banks and keep safe from financial crises }\end{array}$ & & & & & \\
\hline $\begin{array}{l}9 \text { Islamic banks away from low and high interests risks because it does not deal } \\
\text { with }\end{array}$ & & & & & \\
\hline C- meet the needs of customers for Islamic banking products & $\begin{array}{l}\text { Agree } \\
\text { strongly }\end{array}$ & agree & $\begin{array}{l}\text { Not } \\
\text { sure }\end{array}$ & $\begin{array}{l}\text { Not } \\
\text { agree }\end{array}$ & $\begin{array}{l}\text { Not agree } \\
\text { strongly }\end{array}$ \\
\hline 10 Customer requests Islamic products cannot be provided in traditional banks & & & & & \\
\hline $\begin{array}{l}11 \text { Islamic products wide and variety also differ in nature of dealing and did not stem } \\
\text { from one source like traditional based on profit }\end{array}$ & & & & & \\
\hline $\begin{array}{l}12 \text { Islamic banking products achieve customers need because it fulfill the diverse } \\
\text { desires }\end{array}$ & & & & & \\
\hline 13 Islamic products provide safety to customers because it stems from Islamic rule & & & & & \\
\hline D- success of shifting in global banks & $\begin{array}{l}\text { Agree } \\
\text { strongly }\end{array}$ & agree & $\begin{array}{l}\text { Not } \\
\text { sure }\end{array}$ & $\begin{array}{l}\text { Not } \\
\text { agree }\end{array}$ & $\begin{array}{l}\text { Not agree } \\
\text { strongly }\end{array}$ \\
\hline $\begin{array}{l}14 \text { The reason for the shifting was due to the success of international bank experiences } \\
\text { to Islamic banks or open department }\end{array}$ & & & & & \\
\hline $\begin{array}{l}15 \text { The bank took his decision for shifting into Islamic bank after studying other banks } \\
\text { shifting with success }\end{array}$ & & & & & \\
\hline 16 The failure of past experiences affect negatively on shifting decision & & & & & \\
\hline
\end{tabular}


Annex No 2

First subject :compliance with Shariah (Islamic Law)

\begin{tabular}{|c|c|c|c|}
\hline \multicolumn{3}{|c|}{ Banks faced customer are demanding Islamic products } & \multirow[t]{2}{*}{ Q1 } \\
\hline & Total & $\%$ & \\
\hline Strongly disagree & 0 & $0 \%$ & \\
\hline Disagree & 1 & $5 \%$ & \\
\hline Not sure & 2 & $10 \%$ & \\
\hline Agree & 4 & $20 \%$ & \\
\hline Strongly agree & 13 & $65 \%$ & \\
\hline Total & 20 & $100 \%$ & \\
\hline & Total & $\%$ & \\
\hline Disagree & 1 & $5 \%$ & \\
\hline Not sure & 2 & $10 \%$ & \\
\hline Agree & 17 & $85 \%$ & \\
\hline Total & 20 & $100 \%$ & \\
\hline
\end{tabular}

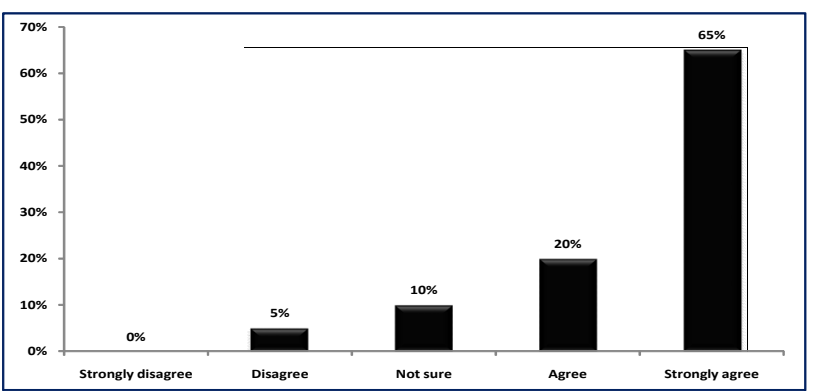

Some customer don't deal with banks because of traditional products(kind of Riba)

\begin{tabular}{|c|c|c|} 
products(kind of Riba) \\
\hline & Total & $\%$ \\
\hline Strongly disagree & 0 & $0 \%$ \\
\hline Disagree & 2 & $10 \%$ \\
\hline Not sure & 2 & $10 \%$ \\
\hline Agree & 4 & $20 \%$ \\
\hline Strongly agree & 12 & $60 \%$ \\
\hline Total & 20 & $100 \%$ \\
\hline
\end{tabular}

\begin{tabular}{|c|c|c|}
\hline & Total & $\%$ \\
\hline Disagree & 2 & $10 \%$ \\
\hline Not sure & 2 & $10 \%$ \\
\hline Agree & 16 & $80 \%$ \\
\hline Total & 20 & $100 \%$ \\
\hline
\end{tabular}

Q2

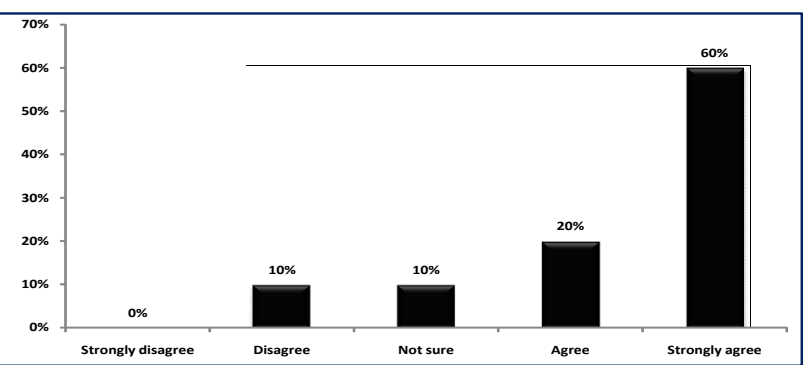

Religious faith strongly controlled the Kuwaiti citizens

\begin{tabular}{|c|c|c|}
\hline & Total & $\%$ \\
\hline Strongly disagree & 2 & $10 \%$ \\
\hline Disagree & 3 & $15 \%$ \\
\hline Not sure & 2 & $10 \%$ \\
\hline Agree & 3 & $15 \%$ \\
\hline Strongly agree & 10 & $50 \%$ \\
\hline Total & 20 & $100 \%$ \\
\hline
\end{tabular}

\begin{tabular}{|c|c|c|}
\hline & Total & $\%$ \\
\hline Disagree & 5 & $25 \%$ \\
\hline Not sure & 2 & $10 \%$ \\
\hline Agree & 13 & $65 \%$ \\
\hline Total & 20 & $100 \%$ \\
\hline
\end{tabular}

Q3

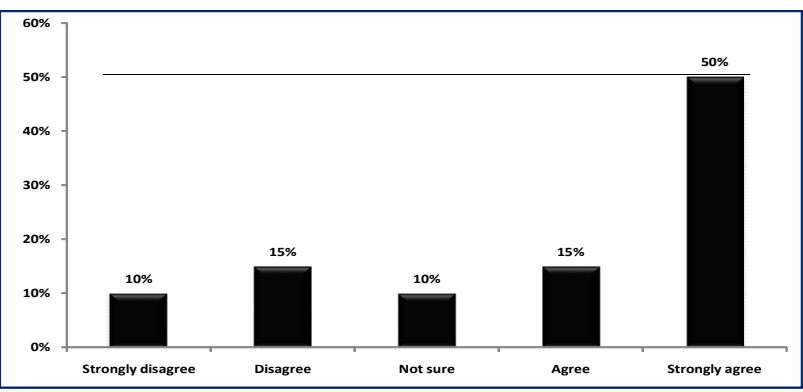

Number of customers increased when providing Islamic products.

\begin{tabular}{|c|c|}
\multicolumn{2}{|c|}{ Number of customers increased when providing Islamic products. } \\
\hline
\end{tabular}

\begin{tabular}{|c|c|c|}
\hline & Total & $\%$ \\
\hline Disagree & 0 & $0 \%$ \\
\hline Not sure & 1 & $5 \%$ \\
\hline Agree & 19 & $95 \%$ \\
\hline Total & 20 & $100 \%$ \\
\hline
\end{tabular}

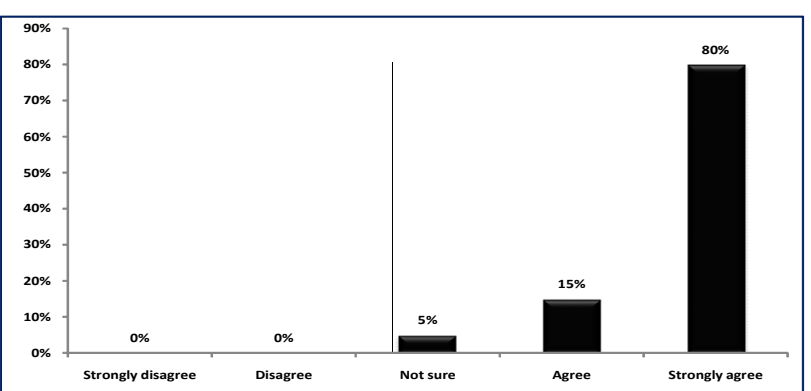

\begin{tabular}{|c|c|c|}
\hline \multicolumn{3}{|c|}{$\begin{array}{l}\text { Is decision to shift into Islamic banks because of the demand of } \\
\text { Islamic products. }\end{array}$} \\
\hline & Total & $\%$ \\
\hline Strongly disagree & 3 & $15 \%$ \\
\hline Disagree & 3 & $15 \%$ \\
\hline Not sure & 4 & $20 \%$ \\
\hline Agree & 2 & $10 \%$ \\
\hline Strongly agree & 8 & $40 \%$ \\
\hline Total & 20 & $100 \%$ \\
\hline & Total & $\%$ \\
\hline Disagree & 6 & $30 \%$ \\
\hline Not sure & 4 & $20 \%$ \\
\hline Agree & 10 & $50 \%$ \\
\hline Total & 20 & $100 \%$ \\
\hline
\end{tabular}

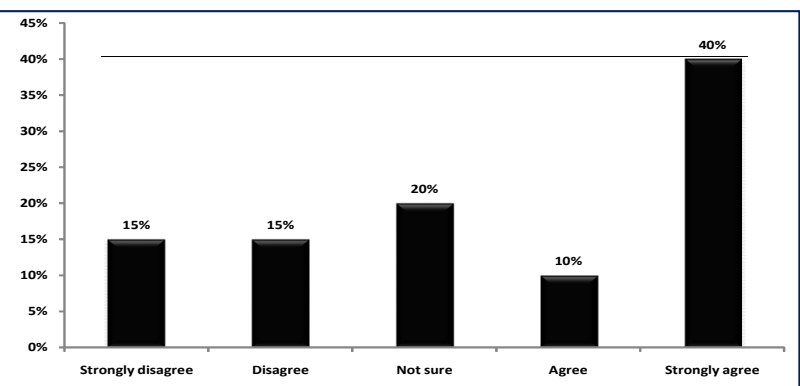


Annex No 3

Second subject: Low rate of the risk and increase of the profit

\begin{tabular}{|c|c|c|c|}
\hline \multicolumn{3}{|c|}{ Islamic products less risk than traditional products(banks products) } & \multirow[t]{2}{*}{ Q6 } \\
\hline & Total & $\%$ & \\
\hline Strongly disagree & 0 & $0 \%$ & \\
\hline Disagree & 1 & $5 \%$ & \\
\hline Not sure & 1 & $5 \%$ & \\
\hline Agree & 2 & $10 \%$ & \\
\hline Strongly agree & 16 & $80 \%$ & \\
\hline Total & 20 & $100 \%$ & \\
\hline & Total & $\%$ & \\
\hline Disagree & 1 & $5 \%$ & \\
\hline Not sure & 1 & $5 \%$ & \\
\hline Agree & 18 & $90 \%$ & \\
\hline Total & 20 & $100 \%$ & \\
\hline
\end{tabular}

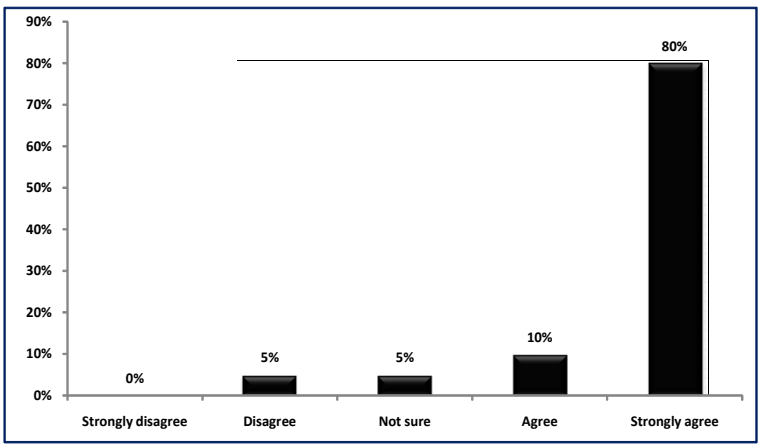

\section{Participation concept enhances the profits because not dealing with credits} and recovery of money

\begin{tabular}{|c|c|c|}
\hline & Total & $\%$ \\
\hline Strongly disagree & 0 & $0 \%$ \\
\hline Disagree & 0 & $0 \%$ \\
\hline Not sure & 2 & $10 \%$ \\
\hline Agree & 3 & $15 \%$ \\
\hline Strongly agree & 15 & $75 \%$ \\
\hline Total & 20 & $100 \%$ \\
\hline
\end{tabular}

\begin{tabular}{|c|c|c|}
\hline & Total & $\%$ \\
\hline Disagree & 0 & $0 \%$ \\
\hline Not sure & 2 & $10 \%$ \\
\hline Agree & 18 & $90 \%$ \\
\hline Total & 20 & $100 \%$ \\
\hline
\end{tabular}

Q7

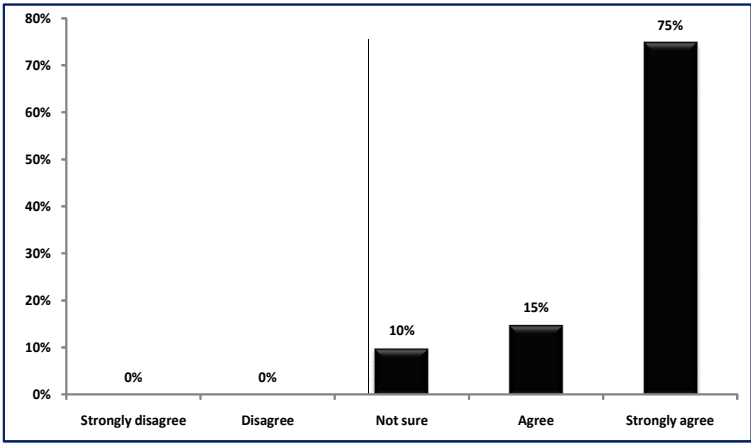

Is the reason behind taking shifting decision because of the profits gained from Islamic banks and keep safe from financial crisis

\begin{tabular}{|c|c|c|}
\hline & Total & $\%$ \\
\hline Strongly disagree & 0 & $0 \%$ \\
\hline Disagree & 0 & $0 \%$ \\
\hline Not sure & 1 & $5 \%$ \\
\hline Agree & 2 & $10 \%$ \\
\hline Strongly agree & 17 & $85 \%$ \\
\hline Total & 20 & $100 \%$ \\
\hline
\end{tabular}

\begin{tabular}{|c|c|c|}
\hline & Total & $\%$ \\
\hline Disagree & 0 & $0 \%$ \\
\hline Not sure & 1 & $5 \%$ \\
\hline Agree & 19 & $95 \%$ \\
\hline Total & 20 & $100 \%$ \\
\hline
\end{tabular}

Islamic banks away from low and high interest risks because it does not deal with

\begin{tabular}{|c|c|c|}
\hline & Total & $\%$ \\
\hline Strongly disagree & 3 & $15 \%$ \\
\hline Disagree & 2 & $10 \%$ \\
\hline Not sure & 2 & $10 \%$ \\
\hline Agree & 3 & $15 \%$ \\
\hline Strongly agree & 10 & $50 \%$ \\
\hline Total & 20 & $100 \%$ \\
\hline
\end{tabular}

\begin{tabular}{|c|c|c|}
\hline & Total & $\%$ \\
\hline Disagree & 5 & $25 \%$ \\
\hline Not sure & 2 & $10 \%$ \\
\hline Agree & 13 & $65 \%$ \\
\hline Total & 20 & $100 \%$ \\
\hline
\end{tabular}

Q8

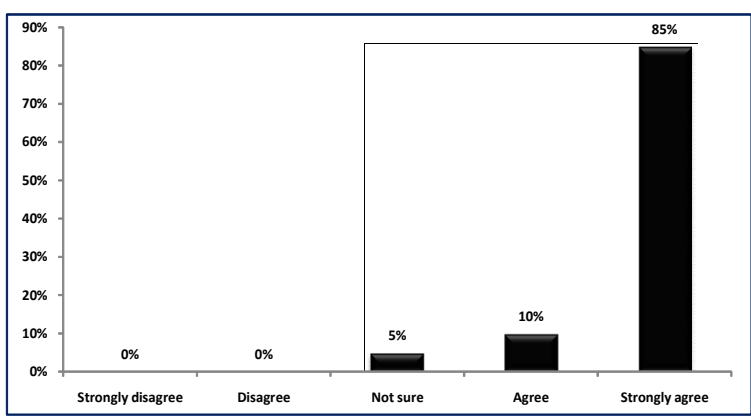

Q9

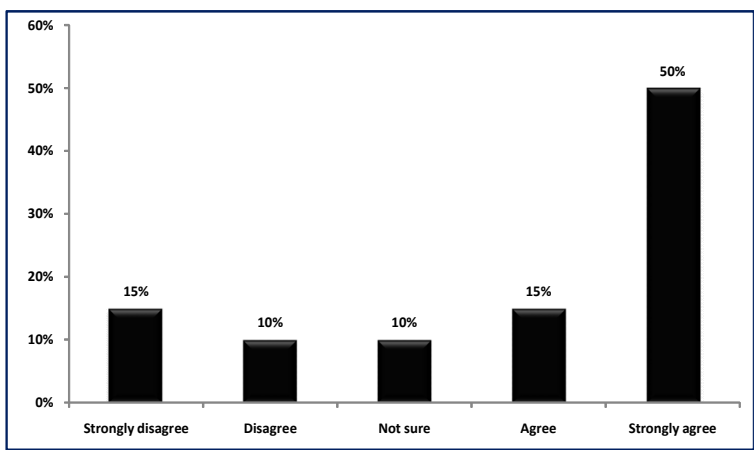


Annex No 4

Third subject:Meet the needs of customers for Islamic banking products.



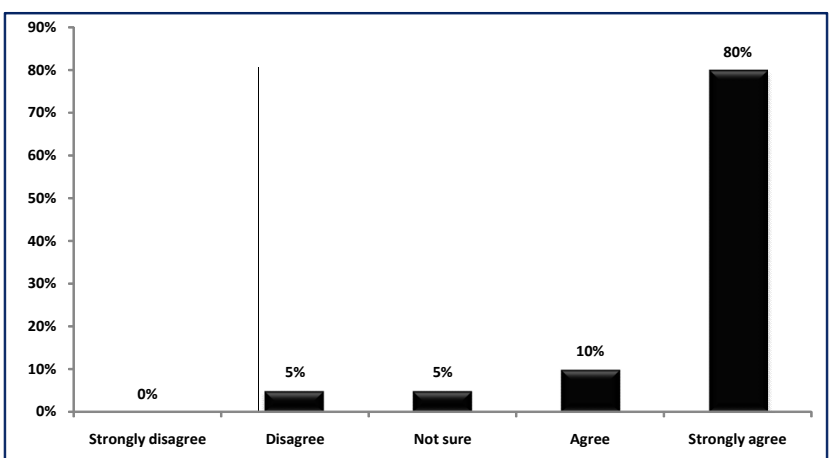

Islamic products wide and variety also differ in nature of dealing and did not stem from one source like traditional based on profit

\begin{tabular}{|c|c|c|}
\hline & Total & $\%$ \\
\hline Strongly disagree & 0 & $0 \%$ \\
\hline Disagree & 0 & $0 \%$ \\
\hline Not sure & 2 & $10 \%$ \\
\hline Agree & 3 & $15 \%$ \\
\hline Strongly agree & 15 & $75 \%$ \\
\hline Total & 20 & $100 \%$ \\
\hline
\end{tabular}

\begin{tabular}{|c|c|c|}
\hline & Total & $\%$ \\
\hline Disagree & 0 & $0 \%$ \\
\hline Not sure & 2 & $10 \%$ \\
\hline Agree & 18 & $90 \%$ \\
\hline Total & 20 & $100 \%$ \\
\hline
\end{tabular}

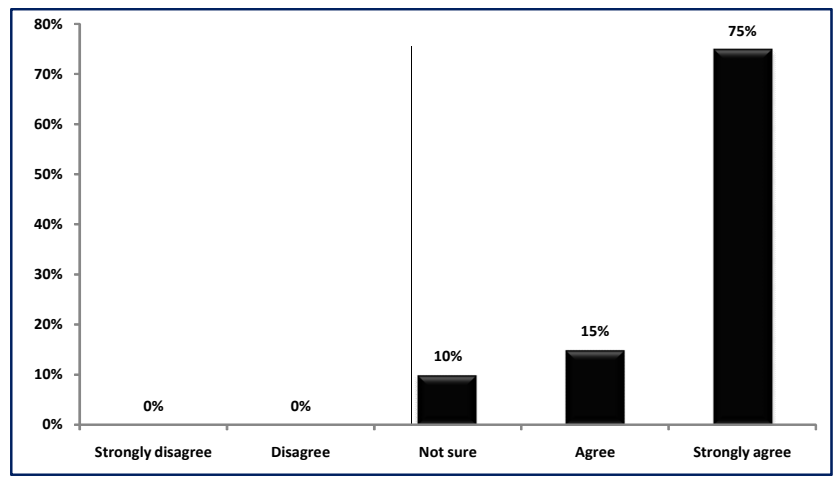

Islamic banking products achieve customers need because it fulfill the diverse desire

\begin{tabular}{|c|c|c|} 
fulfill the diverse desire \\
\hline & Total & $\%$ \\
\hline Strongly disagree & 1 & $5 \%$ \\
\hline Disagree & 1 & $5 \%$ \\
\hline Not sure & 2 & $10 \%$ \\
\hline Agree & 3 & $15 \%$ \\
\hline Strongly agree & 14 & $70 \%$ \\
\hline Total & 21 & $105 \%$ \\
\hline
\end{tabular}

\begin{tabular}{|c|c|c|}
\hline & Total & $\%$ \\
\hline Disagree & 2 & $10 \%$ \\
\hline Not sure & 2 & $10 \%$ \\
\hline Agree & 17 & $85 \%$ \\
\hline Total & 21 & $105 \%$ \\
\hline
\end{tabular}

Islamic products provide safety to customers because it stems from Islamic rule

\begin{tabular}{|c|c|c|}
\hline & Total & $\%$ \\
\hline Strongly disagree & 2 & $10 \%$ \\
\hline Disagree & 3 & $15 \%$ \\
\hline Not sure & 1 & $5 \%$ \\
\hline Agree & 4 & $20 \%$ \\
\hline Strongly agree & 10 & $50 \%$ \\
\hline Total & 20 & $100 \%$ \\
\hline
\end{tabular}

\begin{tabular}{|c|c|c|}
\hline & Total & $\%$ \\
\hline Disagree & 5 & $25 \%$ \\
\hline Not sure & 1 & $5 \%$ \\
\hline Agree & 14 & $70 \%$ \\
\hline Total & 20 & $100 \%$ \\
\hline
\end{tabular}

\section{Q13}

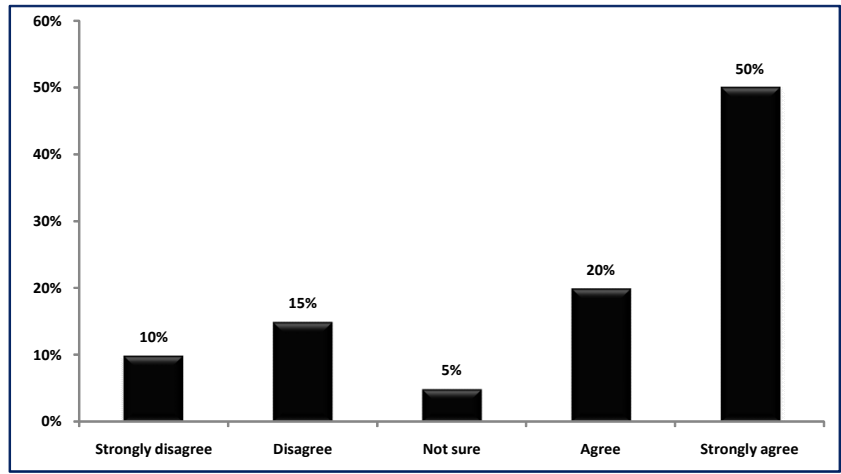


Annex No 5

The Final Subject: Success of shifting in global banks

\begin{tabular}{|c|c|c|c|}
\hline \multicolumn{3}{|c|}{$\begin{array}{l}\text { The reason for the shifting was due to the success of } \\
\text { international bank experiences to Islamic banks or open } \\
\text { department }\end{array}$} & Q14 \\
\hline & Total & $\%$ & \\
\hline Strongly disagree & 0 & $0 \%$ & \\
\hline Disagree & 0 & $0 \%$ & \\
\hline Not sure & 1 & $5 \%$ & \\
\hline Agree & 2 & $10 \%$ & \\
\hline Strongly agree & 17 & $85 \%$ & \\
\hline Total & 20 & $100 \%$ & \\
\hline & Total & $\%$ & \\
\hline Disagree & 0 & $0 \%$ & \\
\hline Not sure & 1 & $5 \%$ & \\
\hline Agree & 19 & $95 \%$ & \\
\hline Total & 20 & $100 \%$ & \\
\hline
\end{tabular}



\begin{tabular}{|c|c|c|c|}
\hline \multicolumn{3}{|c|}{$\begin{array}{l}\text { The bank took his decision of shifting to Islamic bank after } \\
\text { studying other banks shifting with success }\end{array}$} & Q15 \\
\hline & Total & $\%$ & \\
\hline Strongly disagree & 0 & $0 \%$ & \\
\hline Disagree & 1 & $5 \%$ & \\
\hline Not sure & 2 & $10 \%$ & \\
\hline Agree & 2 & $10 \%$ & \\
\hline Strongly agree & 15 & $75 \%$ & \\
\hline Total & 20 & $100 \%$ & \\
\hline & Total & $\%$ & \\
\hline Disagree & 1 & $5 \%$ & \\
\hline Not sure & 2 & $10 \%$ & \\
\hline Agree & 17 & $85 \%$ & \\
\hline Total & 20 & $100 \%$ & \\
\hline
\end{tabular}

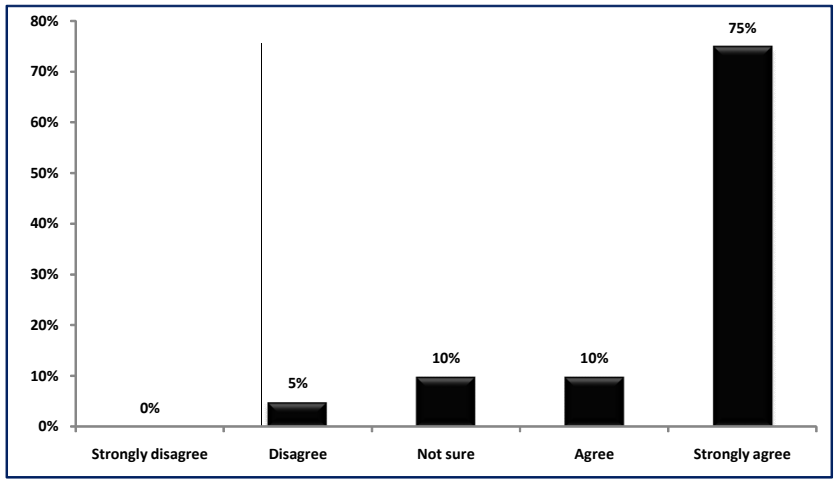

$\begin{aligned} & \text { The failure of past experiences affect negatively on shifting } \\
& \text { lecision }\end{aligned}$
\begin{tabular}{|c|c|c|}
\multirow{2}{*}{ Q16 } \\
\hline Strongly disagree & 2 & $\%$ \\
\hline Disagree & 2 & $10 \%$ \\
\hline Not sure & 3 & $10 \%$ \\
\hline Agree & 3 & $15 \%$ \\
\hline Strongly agree & 10 & $15 \%$ \\
\hline Total & 20 & $50 \%$ \\
\hline \multicolumn{2}{|c|}{} & $100 \%$ \\
\hline Disagree & Total & $\%$ \\
\hline Not sure & 3 & $20 \%$ \\
\hline Agree & 13 & $15 \%$ \\
\hline Total & 20 & $65 \%$ \\
\hline
\end{tabular}

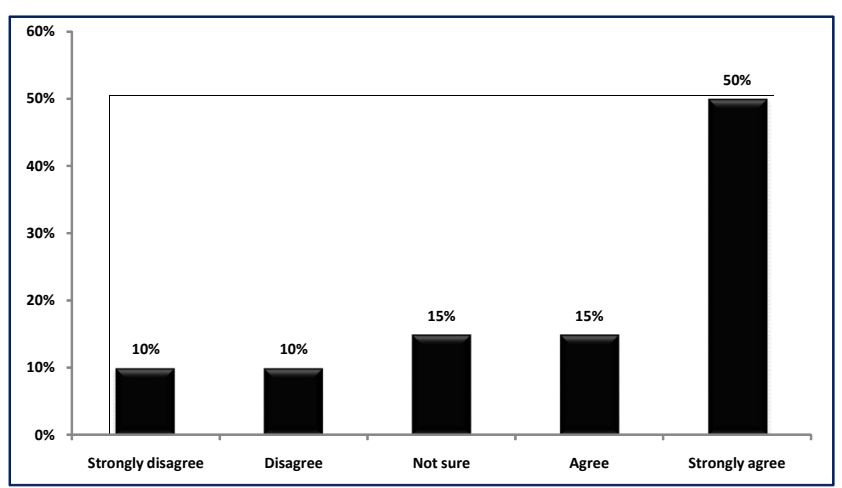

\begin{tabular}{|l|c|}
\hline 5 & Strongly agree \\
\cline { 2 - 2 } & \\
3 & Agree \\
\hline & Not sure \\
\hline 1 & Disagree \\
\cline { 2 - 2 } & Strongly disagree \\
\end{tabular}

